\title{
KUNCI MAGNETIS DENGAN SINYAL DTMF \\ BERBASIS MIKROKONTROLER AT89C51
}

\author{
Oleh \\ Ketut Udy Ariawan \\ Jurusan Pendidikan Teknik Elektro, Fakultas Teknik dan Kejuruan \\ Universitas Pendidikan Ganesha \\ udyariawan@gmail.com
}

\begin{abstract}
ABSTRAK
Keinginan untuk mengamankan suatu barang atau suatu tempat yang bersifat pribadi sehingga menjamin keamanan privasi kita, maka diperlukan suatu peralatan yang tidak dapat diakses oleh orang lain sehingga yang memiliki akses hanya yang dapat menggunakannya saja. Hal ini terjawab dengan adanya kunci elektronik dengan password atau sandi, tetapi hal ini tidaklah efisien apabila kita lupa nomor sandi sehingga kita sering mengalami kesulitan.Kunci magnetis dengan sinyal DTMF berbasis mikrokontroler AT89C51 merupakan kunci elektronik magnetis menggunakan sistem sinyal DTMF yang berfungsi sebagai kunci pengaman untuk suatu ruangan tanpa harus mengingat password atau sandi.

Perancangan dan pembuatan sistem ini berdasarkan pada gagasan untuk mendapatkan suatu sistem yang otomatis, aman dan efektif dalam penggunaannya yang kemudian diaplikasikan pada sistem pembuka pintu, sehingga akan mempermudah proses penguncian dan membuka atau menutup pintu secara otomatis. Untuk merealisasikan sistem tersebut tentu saja tidak dimungkinkan untuk membuat alat sesungguhnya yang bisa langsung digunakan, namun dengan mengambil prinsip yang sama alat yang dibuat dibatasi pada ukurannya sehingga dihasilkan alat miniatur (lebih kecil) dari ukuran sesungguhnya. Dalam perancangan suatu sistem yang otomatis diperlukan suatu sistem kontrol yang mampu memproses setiap masukan menjadi keluaran yang sesuai dengan yang diharapkan, oleh sebab itu perancangan menggunakan sistem yang dapat diprogram, yaitu mikrokontroler AT89C51 sebagai komponen kontrol utama.

Berdasarkan hasil pengujian rangkaian sensor kartu, rangkaian switch sebagai pendeteksi (sensor) pintu, rangkaian penggerak relay, rangkaian dekoder DTMF, rangkaian pre-amp kartu magnetis, dan pengisian data DTMF pada kartu, maka alat yang dibuat dapat berfungsi dengan baik sesuai dengan yang direncanakan sebelumnya.
\end{abstract}

Kata kunci: Mikrokontroler, DTMF, Sensor.

The desire to secure an item or a place that is private so as to guarantee the security of our privacy, it would require an apparatus that can not be accessed by other people so that access can only use it. It missed by the electronic key with a password, but it is not efficient when we forget the password so we often have difficulty. DTMF signal magnetic lock with a AT89C51 microcontroller-based electronic key magnetically using DTMF signaling system that serves as a safety lock for a room without having to remember a password.

Design and manufacture of these systems is based on the idea to get a system that is automated, safe and effective in the use of which is then applied to the door opening systems, which will simplify the process of locking and opening or closing the door automatically. To realize the system is of course not possible to make a real tool that can be directly used, but by taking the same principles that made the tool is limited in its size to produce miniature tool (smaller) than the actual size. In designing a system that automatically takes a control system that is capable of processing any input into output as 
expected, and therefore the design using a system that can be programmed, ie the microcontroller AT89C51 as the main control components.

Based on the results of testing sensor circuit cards, circuit switch as a detector (sensor) door, a series of driving relays, circuit DTMF decoder, a series of pre-amp magnetic card, and charging data DTMF on the card, then the tool is made to function properly as planned previously.

Keywords: Microcontroller, DTMF, Sensor.

\section{PENDAHULUAN}

Perubahan teknologi dewasa ini berkembang semakin cepat. Peralatan yang lebihmodern bermunculan menggantikan peralatan-peralatan yang dioperasikandengan sistem manual.Keinginan untuk mengamankan suatu barang atau suatutempat yang bersifat pribadi sehingga menjamin keamanan privasi kita, maka diperlukan suatu peralatan yang tidak dapat diakses oleh orang lain sehingga yang memiliki akses hanya yang dapat menggunakannya saja. Hal ini terjawab dengan adanya kunci elektronik dengan password atau sandi, tetapi hal ini tidaklah efisien apabila kita lupa nomor sandisehingga kita sering mengalami kesulitan.Menjawab keinginan dan tuntutan tersebut, maka penulis membuat penelitian dengan judul 'Kunci Magnetis dengan Sinyal DTMF Berbasis Mikrokontroler AT89C51' yang diharapkan dapat menjaga dan menjamin keamanan suatu tempat atau ruangan sehingga tidak sembarang orang dapat memasukinya.

Sistem atau peralatan ini terdiri dari bagian kontrol yang berbasis mikrokontroler AT89C51, yang berfungsi sebagai pengolahan data dari input sistem sehingga menghasilkan keluaran yang sesuai dengan keinginan. Bagian masukan akan berupa detektor dan saklar serta data BCD dari dekoder DTMF yang berfungsi memberikan datamasukan yang menandakan kondisi peralatan ke mikrokontroler. Bagian keluaran akan berupa peralatan mekanik yang bisa menutup dan membuka pintu suatu ruangan.Tujuan khusus dan manfaat dari pembuatan kunci Magnetis dengan Sinyal DTMF ini adalah sebagai berikut:

- Mempelajari serta menerapkan teknologi mikrokontroler dalam suatu karya yang nyata.

- Memberikan keamanan pada suatu barang atau tempat (ruangan) pribadi.

- Bermanfaat bagi penulis khususnya karena dapat menambah ilmu, wawasan serta teknik perakitan suatu peralatan. 
- Bermanfaat bagi masyarakat karena alat ini dapat dipakai secara umum sehingga akan dibuat untuk lebih mudah dioperasikan, efisien dan efektif dalam pengamanan.

- Memanfaatkan teknologi yang sudah ada sehingga mampu menjadi peralatan yang bermanfaat.

Mikroprosesor adalah salah satu jenis komponen digital yang digunakan dalam penelitian ini yang terintegrasi dengan ukuran skala LSI (Large Scale Integration)/VLSI (Veri Large Scale Integration) yang mampu melaksanakan fungsi dari suatu unit pemroses pusat/sentral CPU (Central Processing Unit), sedangkan sistem mikroprosesor adalah suatu sistem yang menggunakan atau memanfaatkan komponen mikro sebagai pengendali operasi dari sistem keseluruhan. Dalam aplikasinya sistem mikroprosesor harus dilengkapi dengan semua komponen utamanya, yaitu mikroprosesor yang berfungsi sebagai CPU, unit input/output (I/O).Memori baca ROM (Read Only Memory) dan memori baca tulis RAM (Random Access Memory). Apabila sebuah mikroprosesor dikombinasikan dengan komunikasi I/O, RAM dan ROM maka akan dihasilkan sebuah mikrokomputer dan bila seluruhnya disatukan dalam satu bentuk chip, maka akan dihasilkan sebuah SCM (Single Chip Microcomputer).

Mikrokontroler merupakan salah satu komponen utama yang digunakan dalam penelitian ini, yaitu tipe AT89C51 yang termasuk ke dalam keluarga MCS-51 dari intel. Sebuah mikrokontroler tidak dapat bekerja apabila belum dimasukkan program lebih dahulu. Fungsi program ini adalah untuk memberi tahu intruksi apa yang harus dikerjakan oleh mikrokontroler. Intruksi adalah suatu susunan bilangan biner tertentu yang akan menghasilkan respon tertentu pula dari mikrokontroler. Intruksi-intruksi perangkat lunak merupakan bahasa mesin yang hanya dapat dimengerti oleh mikroprosesor yang bersangkutan. Dengan kata lain intruksi untuk suatu jenismikrokontroler berbeda dengan intruksi untuk mikrokontroler lainnya.

Salah satu sensor yang digunakan dalam penelitian ini adalah sensor optocoupleryang terdiri dari dua bagian, yaitu pemancar/sumber cahaya yang berupa LED (Ligth Emitting Diode) dan penerima yang berupa sebuah photo transistor.Pada saat menunggu (stanby), photo transistor akan aktif karena menerima cahaya dari pemancar LED, hal ini menyebabkan tegangan VCC langsung terhubung ke ground sehingga tegangan pada keluaran (out) menjadi 0 (low). Apabila ada suatu objek yang menghalangi transmisi sinar dari LED maka photo transistor akan tidak aktif, hal ini akan menyebabkan tegangan keluaran (out) akan sama dengan tegangan VCC atau high.Pada saat menunggu (stanby), photo transistor akan aktif karena menerima cahaya dari 
pemancar LED, hal ini menyebabkan tegangan VCC langsung terhubung ke ground sehingga teganganpada keluaran(out) menjadi 0 (low). Apabila ada suatu objek yang menghalangi transmisi sinar dari LED maka photo transistor akan tidak aktif, hal ini akan menyebabkan tegangan keluaran (out) akan sama dengan tegangan VCC atau high.

MT8870 merupakan sebuah IC penerima DTMF (Dual Tone Multi Frequency) lengkap yang digunakan dalam penelitian ini, yang merupakan gabungan dari filter bandsplit dan fungsi-fungsi dekoder digital. Bagian filter menggunakan teknik switched capasitor untuk kelompok frekuensi tinggi dan kelompok frekuensi rendah. Dekoder menggunakan teknik perhitungan digital untuk mendeteksi dan mengkodekan 16 pasang tone DTMF dalam kode 4 bit. IC MT8870 berfungsi sebagai dekoder sinyal DTMF, yaitu untuk menterjemahkan sinyal DTMF menjadi bilangan BCD dimana bilangan BCD inilah yang kemudian akan masuk ke mikrokontroler.

Pengendali solenoid merupakan sebuah rangkaian lilitan yang menghasilkan medan magnet dimana medan magnet tersebut untuk menarik sebuah batang besi. Dalam sistem yang dirancang ini solenoid berfungsi untuk menarik batang pengunci pintu. Solenoid yang digunakan dalam sistem ini memiliki tegangan kerja sebesar 12 Volt dan konsumsi arus sebesar 4 Ampere.

Motor adalah mesin yang dapat mengubah energi listrik menjadi energi mekanis. Jenis motor yang digunakan dalam penelitian ini adalah motor DC. Konstruksi motor DC sangat mirip dengan generator DC, satu perbedaan dalam konstruksi yang perludiperhatikan, yaitu antara motor dan generator. Motor kerap kali dioperasikan di lokasi yang mungkin mudah mendapat kerusakan mekanis, debu, lembab, atau korosi maka motor biasanya lebih tertutup rapat daripada generator.

Kunci magnetis yang digunakan dalam penelitian ini adalah sebuah kartu, dimana pada kartu tersebut mempunyai bagian lapisan yang mengandung medan magnet atau lapisan magnet dimana pada kunci tersebut berisi data magnetis yang akan dirubah kedalam medan listrik. Pada lapisan magnet tersebut dapat diisi sebuah data dari arus listrik dan disimpan dalam kartu tersebut dalam bentuk medan magnet dan data magnetis tersebut adalah suatu kode dimana kode tersebut akan dirubah kedalam arus listrik dan diperkuat oleh sebuah pre-amp, apabila arus listrik tersebut sudah mencukupi untuk diumpankan ke dalam rangkaian dekoder.

\section{METODE PENELITIAN}

Perancangan dan pembuatan sistem ini berdasarkan pada gagasan untuk mendapatkan suatu sistem yang otomatis, aman dan efektif dalam penggunaannya yang 
kemudian diaplikasikan pada sistem pembuka pintu, sehingga akan mempermudah proses penguncian dan membuka atau menutup pintu secara otomatis.

Untuk merealisasikan sistem tersebut tentu saja tidak dimungkinkan untuk membuat alat sesungguhnya yang bisa langsung digunakan, namun dengan mengambil prinsip yang sama alat yang dibuat dibatasi pada ukurannya sehingga dihasilkan alat miniatur (lebih kecil) dari ukuran sesungguhnya.

Dalam perancangan suatu sistem yang otomatis diperlukan suatu sistem kontrol yang mampu memproses setiap masukan menjadi keluaran yang sesuai dengan yang diharapkan, oleh sebab itu perancang menggunakan sistem yang dapat diprogram, yaitu mikrokontroler AT89C51 sebagai komponen kontrol utama.

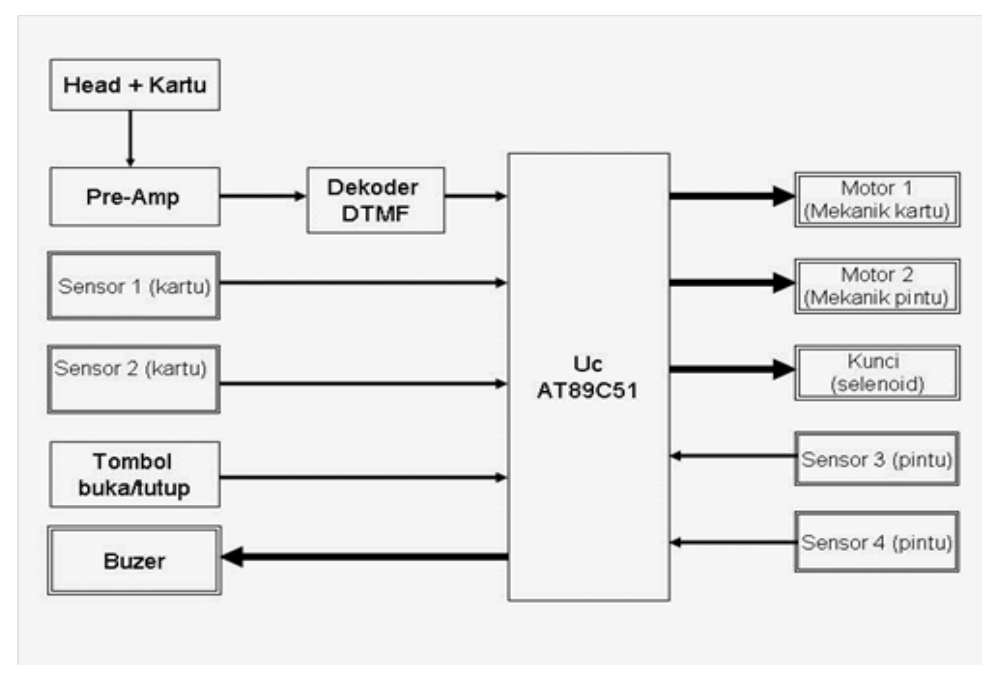

Gambar 1. Diagram blok kunci magnetis dengan sinyal DTMF

Cara kerja dari alat yang dirancang ini mulai dari kondisi awal atau cek alat. Pada keadaan awal mikrokontroler akan mengecek alat, yaitu dengan mendeteksi kondisi kartu apakah ada kartu pada mekanik, dan jika kondisi pintu terbuka maka sistem akan menutup pintu terlebih dahulu, begitu jugajika ada kartu kartu pada mekanik sistem akan mengeluarkan kartu terlebih dahulu. Setelah semua siap sistem akan mendeteksi sensor 1 sebagai tanda ada kartu yang masuk, dan tombol buka atau tutup pintu dari dalam. Apabila ada salah satu yang aktif maka sistem akan mulai bekerja. 


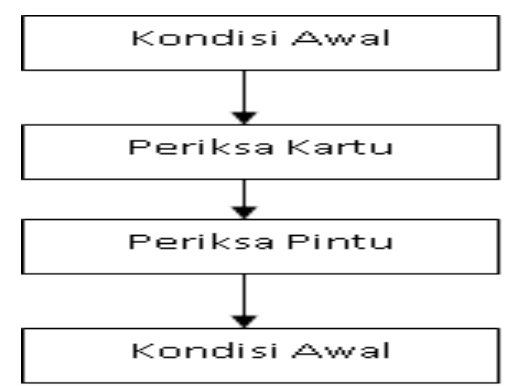

Gambar 2. Algoritma kondisi awal atau cek alat

Gambar diatas (Gambar 2) menunjukkan algoritma pada kondisi awal. Pada kondisi ini mikrokontroler akan memeriksa kartu apakah ada kartu pada mekanik,jika ada kartu maka kartu akan dikeluarkan dulu selanjutnya dan memeriksa keadaan pintu apabila pintu dalam keadaan terbuka maka pintu akan ditutup terlebih dahulu.

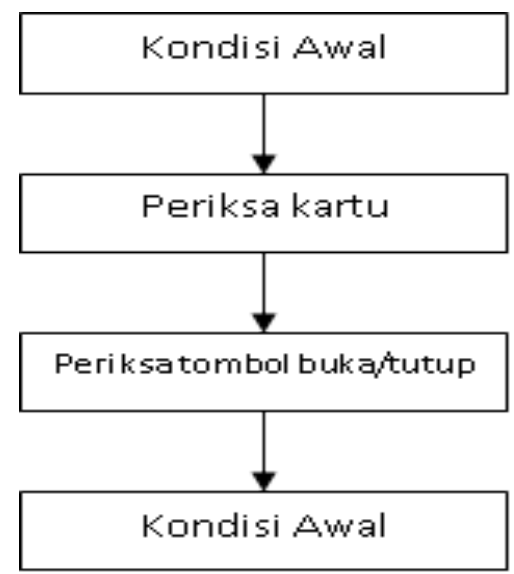

Gambar 3. Algoritma program utama

Selanjutnya adalah algoritma program utama (Gambar 3) dimana pada kondisi awal mikrokontroler akan memeriksa kartu dan apabila kartu masuk maka dilanjutkan dengan sub program kartu masuk dan akan memproses data pada kartu. Tetapi jika keadaan tidak ada kartu mikrokontroler juga memeriksa tombol buka tutup dan jika tombol buka tutup aktif maka selanjutnya akan masuk ke program tombol buka/tutup. 


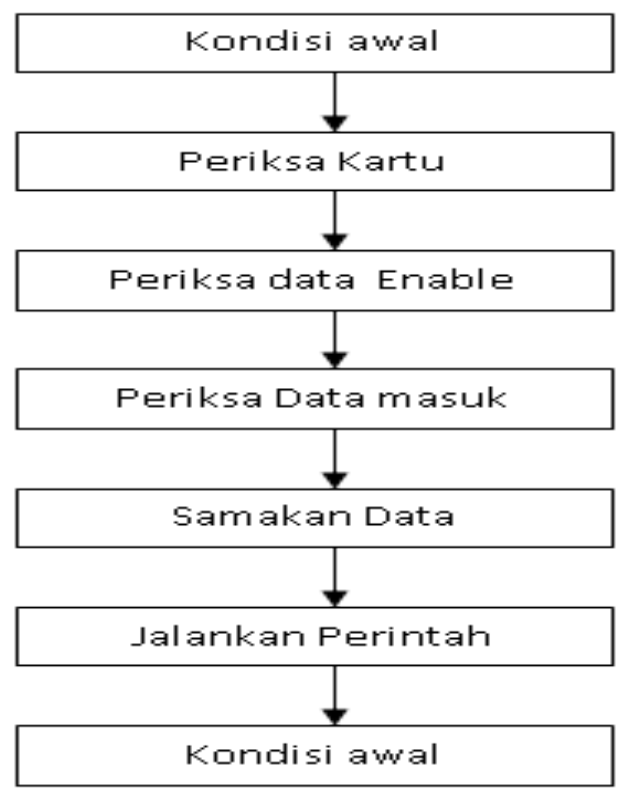

Gambar 4. Algoritma sub kartu masuk

Berikutnya adalah algoritma sub kartu masuk (Gambar 4) pada kondisi awal mikrokontroler akan mendeteksi kartu yang masuk dan selanjutnya akan mendeteksi data enable apakah data baru telah masuk atau belum, kemudian data yang masuk dari kartu akan diperiksa dan disamakan data tersebut dengan data yang berada pada memori pada mikrokontroler, dan apabila data tersebut telah masuk maka mikrokontroler akan menjalankan perintah. Apabila telah selesai maka akan kembali ke kondisi awal.

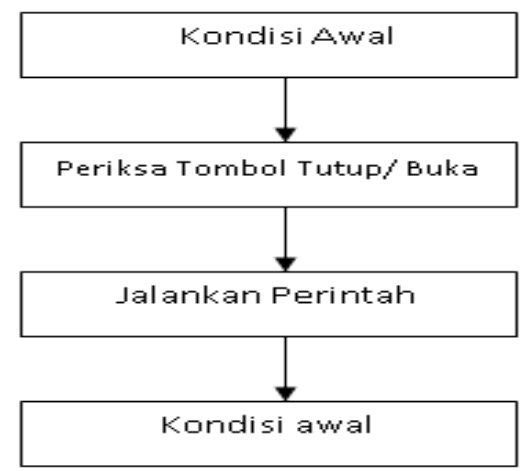

Gambar 5. Algoritma buka pintu dengan tombol

Berikutnya adalah algoritma buka pintu dengan tombol (Gambar 5) pada kondisi awal mikrokontroler akan mendeteksiatau memeriksa tombol tutup/buka dan apabila tombol tutup atau buka aktif maka mikrokontroler akan menjalankan perintah.Apabila proses tersebut selesai maka akan kembali ke kondisi awal. 


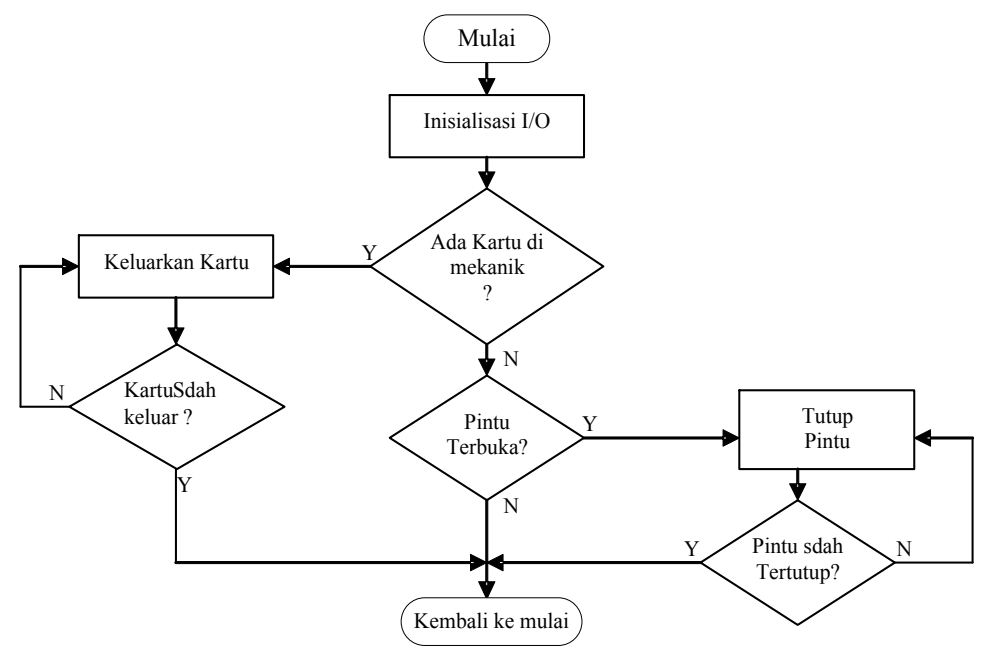

Gambar 6. Flow chart cek kondisi awal

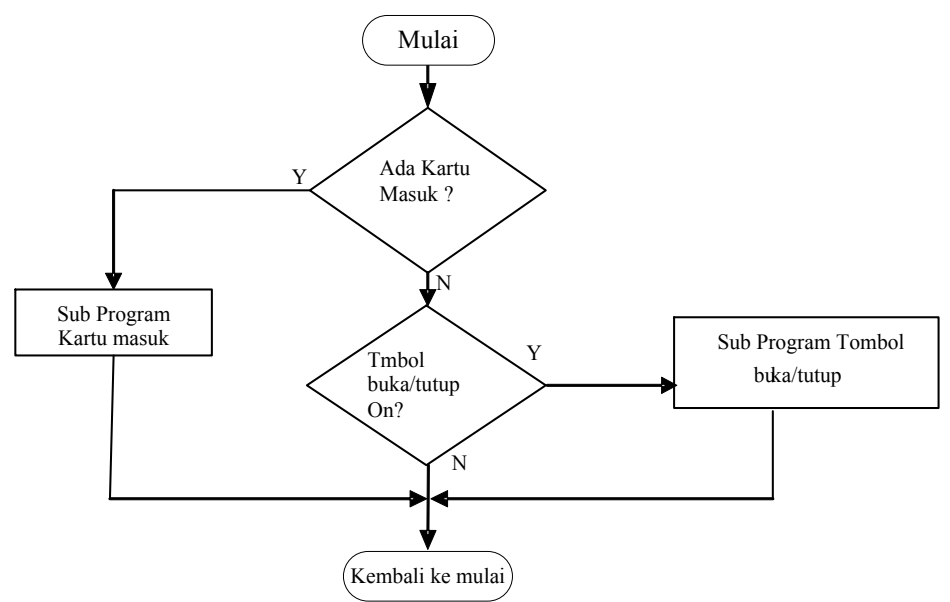

Gambar 7. Flow chart program utama 


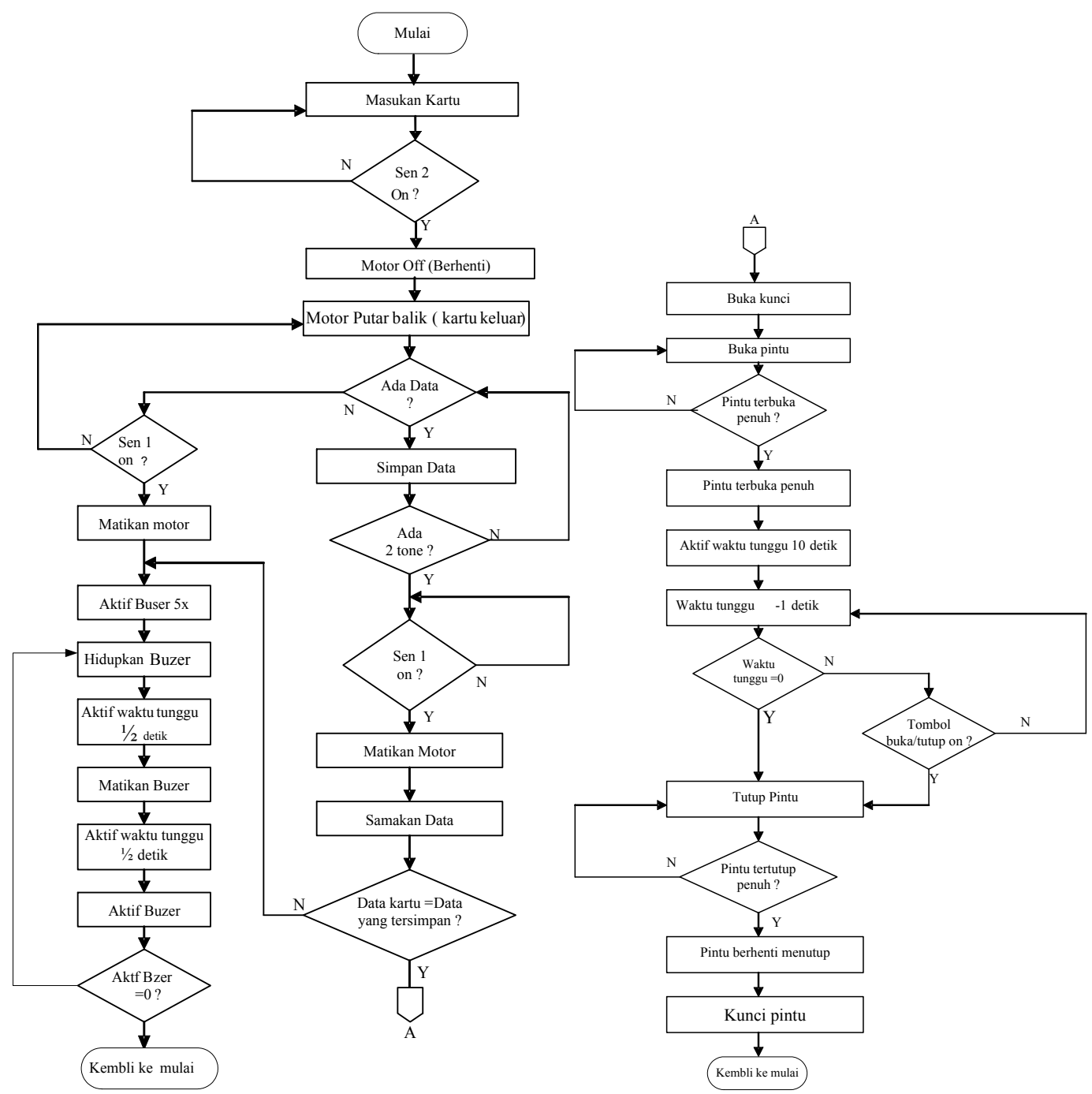

Gambar 8. Flow chartsub program kartu masuk 


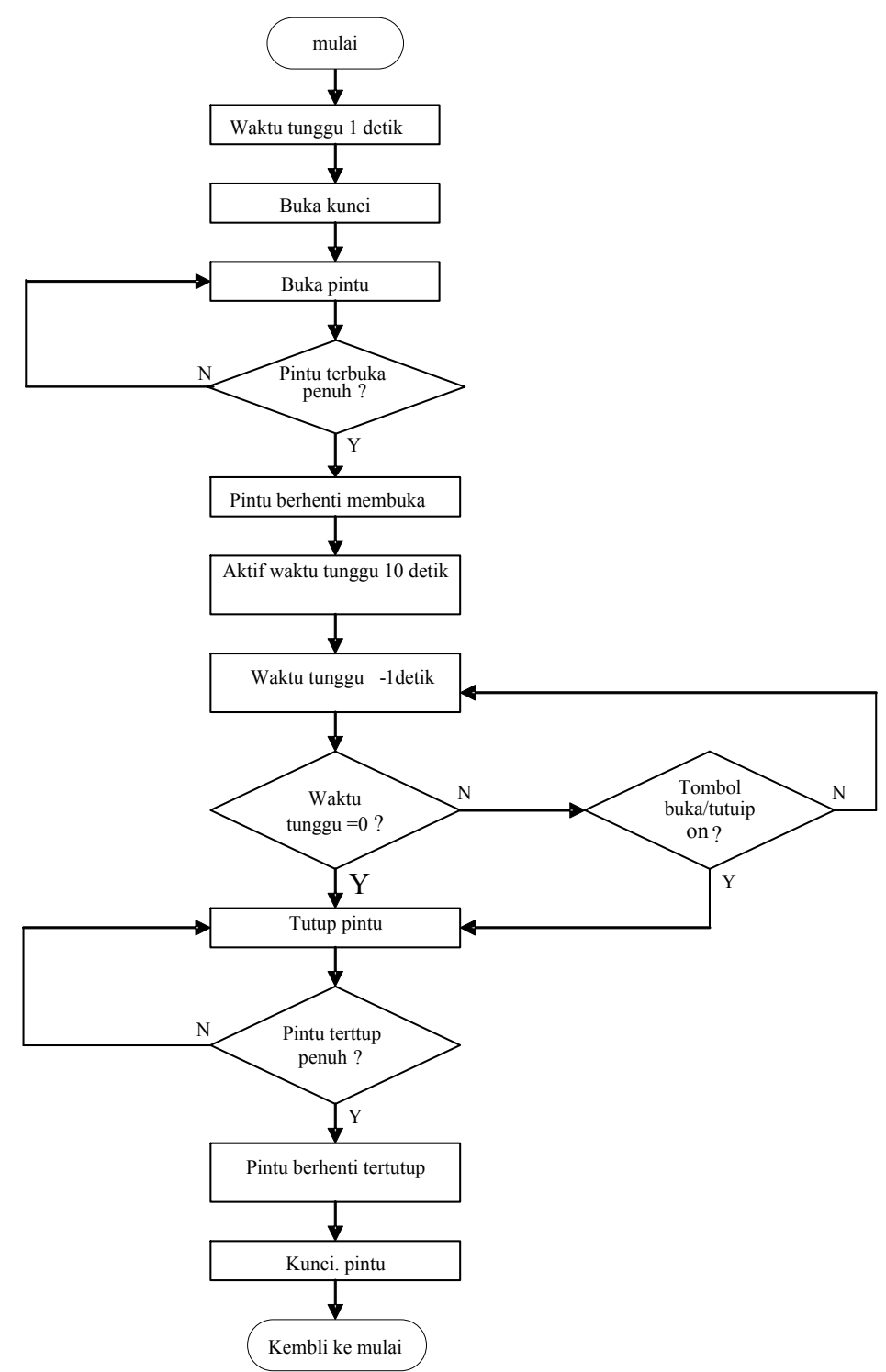

Gambar 9. Flow chartsub program tombol buka/tutup

\section{HASIL PENELITIAN DAN PEMBAHASAN}

Pada bagian ini akan dibahas mengenai cara pengujian dan hasil terhadap bagianbagian alat yang telah dibuat. Pengujian ini dilakukan untuk memastikan bahwa semua bagian alat dan komponen pendukungnya dapat bekerja dengan baik. Pengujian ini meliputi bagian sensor kartu,switch pendeteksi (sensor) pintu, rangkaian penggerak relay, pengujian rangkaian dekoder DTMF, dan pengujian pre-amp kartu magnetis. 


\subsection{Pengujian Rangkaian Sensor Kartu}

Pengujian pada rangkaian relay ini bertujuan untuk mengetahui kondisi output yang diberikanoleh photo transistor. Bentuk dan hasil pengukuran yang diperoleh dapat dilihat pada gambar dan tabel dibawah ini:

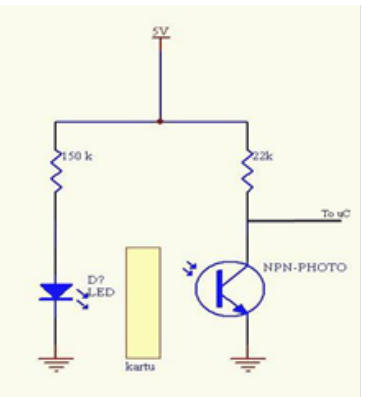

Gambar 10. Rangkaian pengujian sensor kartu

Rangkaian diatas memberi bit keluaran ke mikrokontroler aktif-high.

Tabel 1. Hasil pengujian sensor kartu

\begin{tabular}{|c|c|c|}
\hline Kondisi & Bit Keluaran & TeganganKeluaran \\
\hline siaga (tanpakartu) & 0 & $0 \mathrm{~V}$ \\
terhalangkartu & 1 & $4.6 \mathrm{~V}$ \\
\hline
\end{tabular}

Setelah melakukan pengujian tersebut, ternyata bagian-bagian yang diukur memberikan hasil atau respon sesuai dengan yang diinginkan, dimanapada saat siaga atau tanpa kartu akan mengeluarkan logic 0 yang artinya tegangan keluaran 0 volt dan bila kondisi sensor terhalang kartu maka akan mengeluarkan logic 1 dan mengeluarkan tegangan 4.6 volt.

\subsection{Pengujian Rangkaian Switch sebagai Pendeteksi (Sensor) Pintu}

Pada pengujian rangkaian switch sebagai pendeteksi ini untuk mengetahui kondisi output yang diberikan oleh switch sensor pintu apabila switch ini pada keadaan siaga maka bit keluarannya adalah satu dengan tegangan keluaran 5 volt. Bentuk rangkaian dan hasil pengukuranyang diperoleh, dapat dilihat pada gambar dan tabel dibawah ini: 


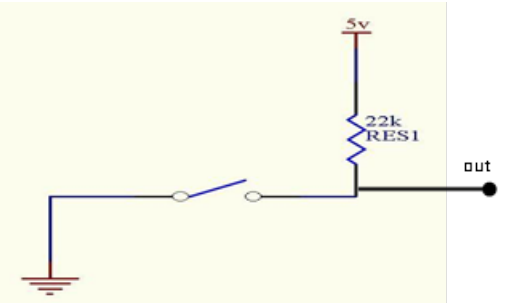

Gambar11. Rangkaian pengujian switch sensor pintu

Tabel 2. Hasil pengujian switch sensor pintu

\begin{tabular}{|c|c|c|}
\hline Kondisi & Bit Keluaran & TeganganKeluaran \\
\hline siaga & 1 & $5 \mathrm{~V}$ \\
tersambung & 0 & $0 \mathrm{~V}$ \\
\hline
\end{tabular}

\subsection{Pengujian Rangkaian Penggerak Relay}

Pengujian pada rangkaian penggerak relay ini bertujuan untuk mengetahui besarnya arus yang mengalir pada basis transistor (BC 547)dan arus pada kolektor yang akan menggerakkan relay. Alat ukur yang digunakan, dipasang seri dengan transistor pada kaki basis dan kolektornya.

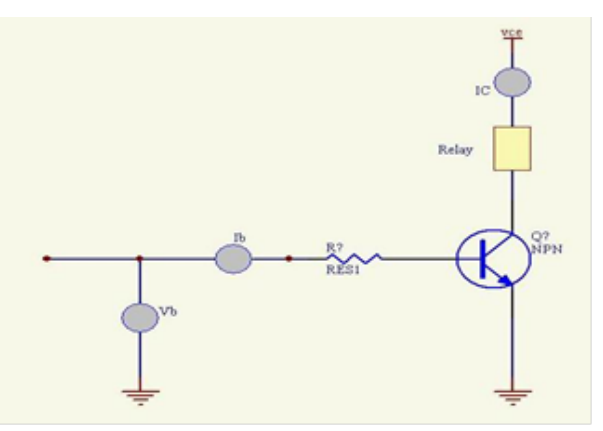

Gambar 12. Rangkaian pengujian penggerak relay

Tabel 3. Hasil pengujian rangkaian penggerak relay

\begin{tabular}{|c|c|c|c|c|c|}
\hline \multicolumn{3}{|c|}{ Perhitungan } & \multicolumn{3}{c|}{ Pengukuran } \\
\hline $\mathrm{Vb}(\mathrm{V})$ & $\mathrm{Ib}(\mathrm{mA})$ & $\mathrm{Ic}(\mathrm{mA})$ & $\mathrm{Vb}(\mathrm{V})$ & $\mathrm{Ib}(\mathrm{mA})$ & $\mathrm{Ic}(\mathrm{mA})$ \\
\hline 5 & 0.36 & 40 & 4.6 & 0.3 & 37 \\
\hline
\end{tabular}

Hasil pengukuran yang didapatkan dari pengujian rangkaian penggerak relay ini dapat dilihat pada Tabel 3. Padatabel diatas terlihat bahwa besar nilai-nilaitegangan dan arus yang didapat dari hasil pengukuran tidak jauh berbeda dengan nilai hasil perhitungan 
yang dibahas pada sub bab rangkaian pengatur kerja motor. Hal ini menunjukkan bahwa rangkaian bekerja dengan baik.

\subsection{Pengujian Rangkaian Dekoder DTMF}

Pengujian pada rangkaian dekoder DTMFdilakukan dengan menggunakan pesawat telepon sebagai sumber sinyal masukan dan LED sebagai indikator keluaran. DimanaL 1 sampai dengan L 4 menunjukkan sinyal tone yang telah dikeluarkan oleh IC MT 8870dan untuk indikasi dari nyalaL5 sebagai tanda pada saat datadi Q1 sampai dengan Q4 siap (sinyal DTMF telah masuk) sehingga setiap perubahan nilai dari keypad akan menyalakan LED L5.

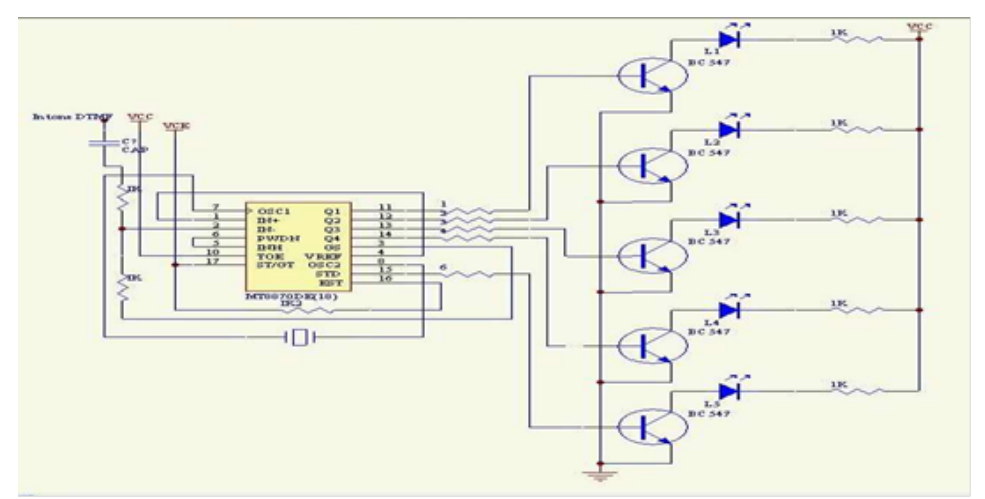

Gambar 13. Rangkaian pengujian dekoder DTMF

Hasil pengujian yang diperoleh dapat dilihat pada Tabel 4, dimana pada tabel tersebut memperlihatkan hasil keluaran dari kaki- kaki pin IC DTMF tersebutsedangkan untuk Tabel 5 memperlihatkan hasil pengujian dengan menggunakan indikator lampu dan hasil dari pengujian tone DTMF ini telah sesuai dengan hasil yangdinginkan, yaitu sesuai dengan keluaran IC DTMF.

Tabel 4. Keluaran dekoderDTMF

\begin{tabular}{|c|c|c|c|c|}
\hline Keypad & Q4 & Q3 & Q2 & Q1 \\
\hline 1 & 0 & 0 & 0 & 1 \\
\hline 2 & 0 & 0 & 1 & 0 \\
\hline 3 & 0 & 0 & 1 & 1 \\
\hline 4 & 0 & 1 & 0 & 0 \\
\hline 5 & 0 & 1 & 0 & 1 \\
\hline 6 & 0 & 1 & 1 & 0 \\
\hline 7 & 0 & 1 & 1 & 1 \\
\hline 8 & 1 & 0 & 0 & 0 \\
\hline
\end{tabular}




\begin{tabular}{|c|c|c|c|c|}
\hline 9 & 1 & 0 & 0 & 1 \\
\hline 0 & 1 & 0 & 1 & 0 \\
\hline$*$ & 1 & 0 & 1 & 1 \\
\hline$\#$ & 1 & 1 & 0 & 0 \\
\hline
\end{tabular}

Tabel 5. Hasil pengujian rangkaian dekoder DTMF

Keterangan: $\quad$ Nilai 1 = Lampu menyala

\begin{tabular}{|c|c|c|c|c|}
\hline Keypad & L5 & L4 & L3 & L1 \\
\hline 1 & 1 & 0 & 0 & 1 \\
\hline 2 & 1 & 0 & 0 & 0 \\
\hline 3 & 1 & 0 & 0 & 1 \\
\hline 4 & 1 & 0 & 1 & 0 \\
\hline 5 & 1 & 0 & 1 & 1 \\
\hline 6 & 1 & 0 & 1 & 0 \\
\hline 7 & 1 & 0 & 1 & 1 \\
\hline 8 & 1 & 1 & 0 & 0 \\
\hline 9 & 1 & 1 & 0 & 1 \\
\hline 0 & 1 & 1 & 0 & 0 \\
\hline$*$ & 1 & 1 & 0 & 1 \\
\hline$\#$ & 1 & 1 & 1 & 0 \\
\hline
\end{tabular}

Nilai 0 = Lampu padam

\subsection{Pengujian Rangkaian Pre-amp Kartu Magnetis}

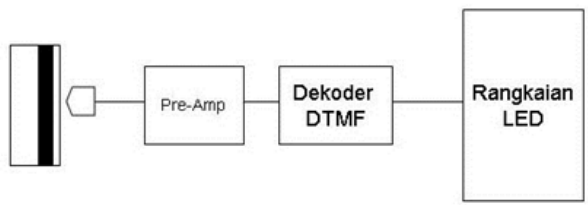

Gambar 14. Blok diagram pengujian pre-amp kartu magnetis

Pengujian pada rangkaian pre-amp ini kartu sebelumnya telah direkamkannada DTMF nilai 1 dan 2 dengan cara menghubungkan head pada mekanik alat dengan tape recorder kemudian nada DTMF yang terekam didapatdari bunyi DTMF telepon yang dihubungkan dengan mikrokontroler pada tape recorder. Untuk meyakinkan nada DTMF tersebut terekam pada pita kartu keluarandarihead dihubungkankembali dengan pre-amp pada alat dan keluarannya disambungkan ke Dekoder DTMF. Sebagai indikator 
digunakan rangkaian LED L1 sampai dengan L4 data Q1 sampai dengan Q4 dan L5 sebagai penanda sinyal telah diterima.

Tabel 6. Hasil pengujian rangkaian pre-amp

\begin{tabular}{|c|c|c|c|c|c|}
\hline Nilaipadakartu & L5 & L4 & L3 & L2 & L1 \\
\hline 1 & 1 & 0 & 0 & 0 & 1 \\
2 & 1 & 0 & 0 & 1 & 0 \\
\hline
\end{tabular}

Keterangan: $\quad$ Nilai 1 = Lampu menyala

Nilai 0 = Lampu padam

Hasil pengujian rangkaian pre-amp ini sekaligus menguji data yang tersimpan pada kartu magnetis tersebut dimana hasilnya dapat dilihat pada Tabel 6, yang memperlihatkan bentuk keluarannya dengan nyala L1 sampai dengan L5 sesuai dengan keluaran yang diinginkan. Setelah melakukan semua tahap pengujian satu persatu pada setiap alat tersebut, ternyata bagian-bagian yang diukur atau diuji memberikan hasil/respon sesuai dengan parameter-parameter yang dinginkan. Hal ini membuktikan bahwa seluruh bagian alat yang dirancang dapat berfungsi dengan baik.

\subsection{Mengisi Data DTMF pada Kartu}

Data pada kartu magnetis yang dipakai dalam alat ini merupakan data DTMF yang telah dituliskan atau write kedalam kartu tersebut. Adapun cara pengisian data tersebut dengan cara merekam data DTMF dari speaker telepon dimana data yang kita inginkan kita tekan dari digit nomor pada telepon tersebut kemudian nada DTMF dari telepon tersebut diumpankan ke pre-amp, setelah data tersebut masuk ke pre-amp maka akan diinformasikan lagi ke head kartu dimana head ini yang akan merubah sinyal listrik atau data DTMF tersebut menjadi medan magnet pada lapisan kartu.Agar pengisian data ke kartu sesuai dengan posisi saat membaca kartu maka diperlukan sebuah rangkaian pengendali motor pada mekanik kartu dengan memanfaatkan rangkaian sistem, yaitu mikrokontroler, dimana mikrokontroler tersebut akan mengatur kartu pada saat keluarmasuk mekanik. Untuk lebih jelasnya dapat digambarkan pada gambar dibawah ini: 


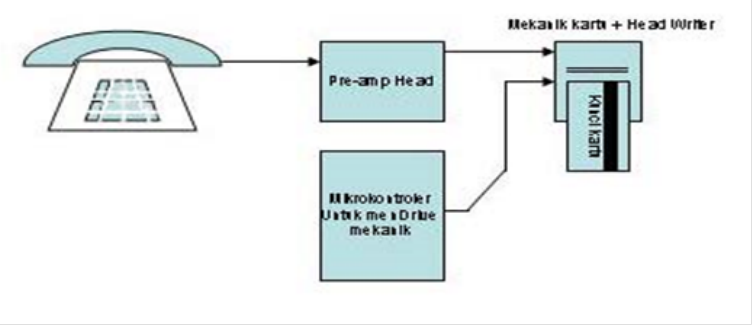

Gambar 15.Pengisian data DTMF pada kartu

\section{SIMPULAN DAN SARAN}

Setelah melakukan perancangan dan perealisasian alat serta melakukan pengukuran dan analisa, maka dapat ditarik kesimpulan bahwa alat yang dibuat ini mempunyai fungsi sebagai alat keamanan suatu ruangan sehingga hanya yang mempunyaikartu dengan sandi atau nomor yang sesuai pada kartu yang dapat membukanya, mudah dioperasikan dan dapat dipakai secara umum, karena hanya dengan memasukan kartu magnetis tersebut maka pintu akan terbuka. Berdasarkan hasil pengujian alat yang dibuat dapat berfungsi dengan baik sesuai dengan yang direncanakan sebelumnya dan mikrokontroler AT89C51 yang digunakan mampu menjalankan pengontrolan berdasarkan beragam masukan digital sehingga dapat mengolah dan mengeluarkan sinyal keluaran yang diinginkan.

Adapun saran-saranyang perlu diketahui untuk pengembangan dan kesempurnaan alat ini adalah:

1. Motor penggerak pintu pada alat ini masih menggunakan motor DC dengan daya yang rendah jadi untuk aplikasi pada pintu yang sebenarnya maka harus diganti dengan motor AC karena diperlukan daya yang lebih besar dan memerlukan driver relay.

2. Pemegang kunci kartu ini dapat diperbanyak sesuai dengan kebutuhan dengan kode pada kartu yang berbeda pada tiap pemegang kartu dan dengan membuat database kode pada mikrokontroler.

3. Untuk pengembanganaplikasi multi pintu atau pintu lebih dari satu dengan satu rangkaianpengontrol maka setiap pintu hanya memerlukanmekanik dan rangkaian pre-amp, dimana outputpre-amp tersebut langsung dikirimkan ke input rangkaian DTMF. 


\section{DAFTAR PUSTAKA}

Intel Corporation, 1994.MCS-51 Microcontroller Family User's Manual,Tersedia pada http://web.mit.edu/6.115/www/document/8051.pdf (diakses tanggal 6 Juli 2013).

Lukito. Ediman, 1991. Dasar-Dasar pemrograman Assembly,Jakarta, PT. Elek Media Komputindo,Gramedia.

Simanulang Gorga, 2003. On-off Controller dengan Bantuan Sinyal DTMF,Jakarta, PT. Elek Media Komputindo.

-------, 2006. Modul Pelatihan Mikrokontroler Atmel 89C51.Yogyakarta, HMJ TE Program Diploma Universitas Gajah Mada. 
JPTK, UNDIKSHA, Vol. 12, No. 2, Juli 2015 : 103-120 